\title{
Stratigraphic correlation of Cambrian-Ordovician deposits along the Himalaya: Implications for the age and nature of rocks in the Mount Everest region
}

\author{
Paul M. Myrow $\dagger$ \\ Department of Geology, Colorado College, Colorado Springs, Colorado 80903, USA
}

Nigel C. Hughes

Department of Earth Sciences, University of California, Riverside, California 92521, USA

Michael P. Searle

Department of Earth Sciences, Oxford University, Parks Road, Oxford, OX1 3PR, UK

C.M. Fanning

Research School of Earth Sciences, The Australian National University, Canberra, ACT 0200, Australia

S.-C. Peng

State Key Laboratory on Paleobiology and Stratigraphy, Nanjing Institute of Geology and Paleontology, Nanjing, 210008, China

S.K. Parcha

Wadia Institute of Himalayan Geology, Dehra Dun, Uttranchal, 248001, India

\section{ABSTRACT}

The depositional age and stratigraphic correlations of metamorphosed and variably deformed rocks of Mount Everest are poorly known because of limited recovery of diagnostic fossils. Detailed study of Cambrian and Ordovician strata from along the length of the Himalaya has produced a coherent stratigraphy that stretches from northern India to Tibet. Our work also demonstrates that the North Col Formation rocks (= Everest series), between the Qomolangma and Lhotse detachments of the South Tibetan detachment system, still locally preserve sedimentary textures and primary stratigraphy that match those within Cambrian strata $\sim 1100 \mathrm{~km}$ to the west in northern India. This demonstrates a coherency of depositional systems and stratigraphic architecture for Cambrian deposits along much of the Himalaya Tethyan margin. It also allows, for the first time, identification of precise depositional ages of several units in the Everest region, in particular, the Yellow Band carbonate and directly underlying siliciclastic strata, which are both shown to be late Middle Cambrian in age. Detrital zircon data presented herein for a sample from these siliciclastic strata

†E-mail: pmyrow@coloradocollege.edu. contain a similar age spectrum to those from Middle Cambrian strata in northern India, as well as grains as young as ca. $526 \mathrm{Ma}$, both of which support the depositional age and continuity of depositional systems along the length of the Himalaya. Highly fractured rocks of the Ordovician lower Chiatsun Group in the hanging wall of the South Tibetan detachment system in Nyalam, $75 \mathrm{~km}$ to the west of Everest, correlate with Ordovician strata of the Mount Qomolangma Formation on Mount Everest. Our correlations indicate that the base of the summit pyramid of Everest, the foot of the "Third Step," is composed of a 60-m-thick, white-weathering thrombolite bed. The top of this ancient microbial deposit crops out only $70 \mathrm{~m}$ below the summit of Mount Everest.

Keywords: India, Himalaya, Parahio Formation, Cambrian, Tethyan, Everest.

\section{INTRODUCTION}

The age and character of the rocks exposed on the summit pyramid of Mount Everest have been highly contested. Early geologists considered the upper part of Everest, including the Yellow Band, to be Permian or younger in age (Odell, 1925; Wager, 1934). Gansser (1964) assigned limestone samples with abundant echinoderm fragments taken from $\sim 6 \mathrm{~m}$ below the summit to the Carboniferous or Permian. In the 1970s, the summit rocks were reinterpreted as being Ordovician in age (Mu et al., 1973; Wang and Zhen, 1975; Yin and Kuo, 1978; Yin, 1987). After the comprehensive geological investigation of the northern slope of Mount Qomolangma by the Chinese Academy of Sciences in 1975, a stratigraphic division was proposed, and the summit limestone was assigned to the Lower to Middle Ordovician (Yin and Kuo 1978; Yin, 1987). This stratigraphy was also used by Burchfiel et al. (1992) in their study of the structures associated with the South Tibetan detachment, a low-angle north-dipping normal fault that separates the "Tethyan" sedimentary series above from the Greater Himalayan sequence of high-grade metamorphic rocks and crustal melt granites below.

Although the strata near the summit of Mount Everest have been correlated with Lower to Middle Ordovician rocks (Yin and Kuo, 1978; Yin, 1987; Burchfiel et al., 1992), almost no age constraint exists for underlying strata that extend down to the high-grade rocks of the Greater Himalayan sequence in the Everest region. Work by Searle (1999, 2003), Law et al. (2004), Searle et al. (2003, 2006), and Jessup et al. (2006) in the Everest massif led to the identification of two north-dipping low-angle normal faults, an upper brittle Qomolangma detachment that cuts

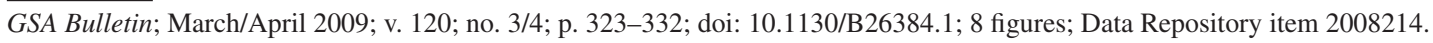


through the summit rocks, and a lower ductile Lhotse detachment that separates greenschistlower-amphibolite-facies pelites of the North Col Formation (= Everest series) above from high-grade sillimanite gneisses, migmatites, and leucogranites beneath. From restoration of the South Tibetan detachment system faults, these authors interpreted the North Col Formation (Everest series) pelites as representing Cambrian and Neoproterozoic protoliths beneath the Yellow Band carbonate, which they interpreted as Ordovician, following earlier reports (e.g., Burchfiel et al., 1992). An understanding of stratigraphic and age relationships of these rocks is critical for deciphering the tectonic history of the Himalaya, particularly the metamorphic protolith of rocks beneath the South Tibetan detachment system.

We present a detailed measured section from above the town of Nyalam, Tibet, $75 \mathrm{~km}$ west of Mount Everest, as well as several sections measured in Cambrian strata along the length of the Indian Himalaya, to demonstrate a coherent stratigraphic framework along the Himalayan Tethyan margin. New detrital zircon data from the Nyalam section verify the stratigraphic correlations and help provide precise depositional ages of strata on Everest. The correlation of the youngest part of the section also allows for the identification of the age and nature of the rocks that make up the base of the summit pyramid on the top of Mount Everest.

\section{LOCATION}

We measured a stratigraphic section across the South Tibetan detachment system, a major down-to-north normal fault that stretches the length of the Himalaya (Burg, 1983; Burg et al., 1984; Burchfiel et al., 1992; Carosi et al., 1998), at a locality $30 \mathrm{~km}$ north of the town of Nyalam, Tibet. The rocks are exposed in cliffs along the north side of a river valley $\sim 5 \mathrm{~km}$ along an unpaved road that branches off the Friendship Highway (Fig. 1). In addition, we examined the same units at a locality $18 \mathrm{~km}$ north of the Rongbuk Monastery, the latter of which is a few kilometers north of Everest base camp. These units are exposed at an altitude of $\sim 5000 \mathrm{~m}$ due to the northward regional dip. Stratigraphic units at this section are similar to those exposed in Nyalam (described next) and are easily traced to Everest itself.

\section{STRATIGRAPHY: NYALAM}

Across the Himalaya, the South Tibetan detachment system separates high-grade metamorphic rocks of the Greater Himalaya sequence (GHS) from sedimentary strata of

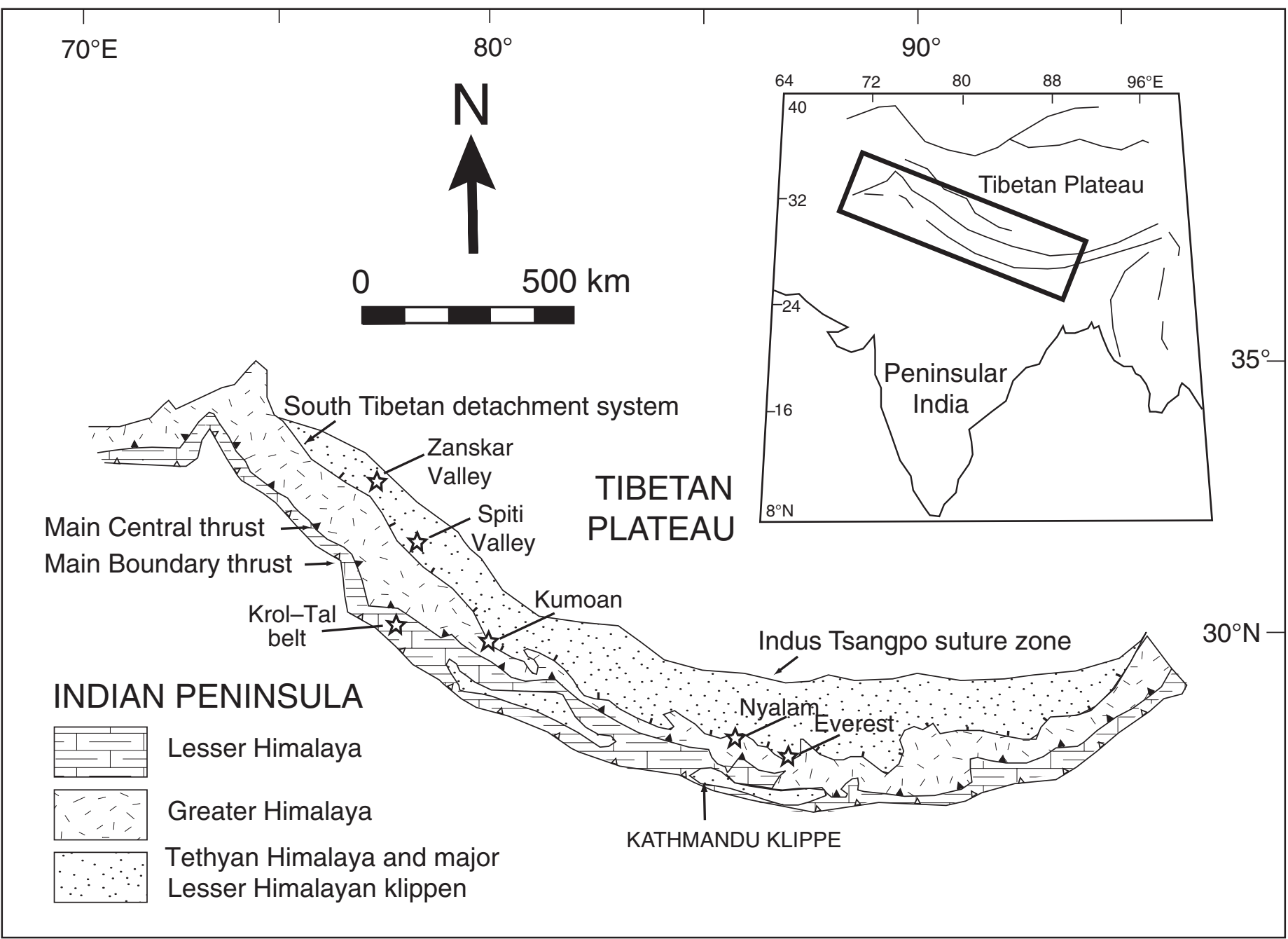

Figure 1. Simplified lithotectonic zones of Himalaya and locations of sections illustrated in Figure 4. Box in inset map shows boundaries of Himalayan map. 
the Tethyan Himalaya (TH) to the north. At this site near Nyalam, Burchfiel et al. (1992) mapped the South Tibetan detachment system at a contact between sheared sedimentary rocks of the footwall and lower-grade Ordovician carbonate in the hanging wall. Here, the South Tibetan detachment system truncates bedding in the hanging wall at a low angle, strikes to the northeast, and dips to the northwest at $20^{\circ}-30^{\circ}$ (Burchfiel et al., 1992). Footwall rocks consist of Cambrian quartzite and psammitic schist with abundant granitic veins, which are capped by a series of dolostone beds that thicken upward into a 109-m-thick, foliated, yellow- to orange-weathering, highly sheared dolostone (Figs. 2 and 3). These metasedimentary rocks (Rouqiecun Group) are equivalents of the North Col Formation (Lombardo et al., 1993), which, in the Everest region, is mapped as biotitemuscovite quartz schist and phyllite with some intercalation of epidote quartz schist, chlorite biotite schist, and thin-banded quartzose marble. On Everest, the North Col Formation is also referred to as the Everest series (Wager, 1934, 1965; Searle, 2003), a nonstratigraphic term that is defined on structural and metamorphic criteria. These rocks of intermediate metamorphic grade are separated from high-grade gneiss and leucogranite (Greater Himalaya sequence proper) below by the lower of two strands of the South Tibetan detachment system mapped in the Everest region, the Lhotse detachment (Searle, 1999, 2003), and from the Ordovician rocks above by the other strand, the Qomolangma detachment. In the Nyalam region, the South Tibetan detachment system, as mapped by Burchfiel et al. (1992), is a single surface that represents a merger of the Qomolangma and Lhotse detachments, a situation similar to the areas north of Everest (Searle, 1999, 2003; Cottle et al., 2007). Rocks of the Rouqiecun Group thus underlie the combined Lhotse and Qomolangma detachments at Nyalam, yet ageequivalent strata of the North Col Formation lie above the Lhotse detachment on Mount Everest. High-grade rocks with various stratigraphic names (Jolmo Lungma Group, Beiao Formation, Nyalam Group) underlie the Rouqiecun in Nyalam (Liu and Einsele, 1994).

The inferred age of these strata and their basic sedimentological character clearly identify them as the continuation of the stratigraphy of the northern Indian margin, which can be traced along the length of the Indian Himalaya from the Zanskar Valley to the Kumaon region (Fig. 4). The thicknesses of sandstone beds (up to $20 \mathrm{~cm}$ ) in the siliciclastic part of the Rouqiecun Group in Nyalam and the shalesandstone ratios are both similar to those of the Parahio Formation of northern India (Myrow

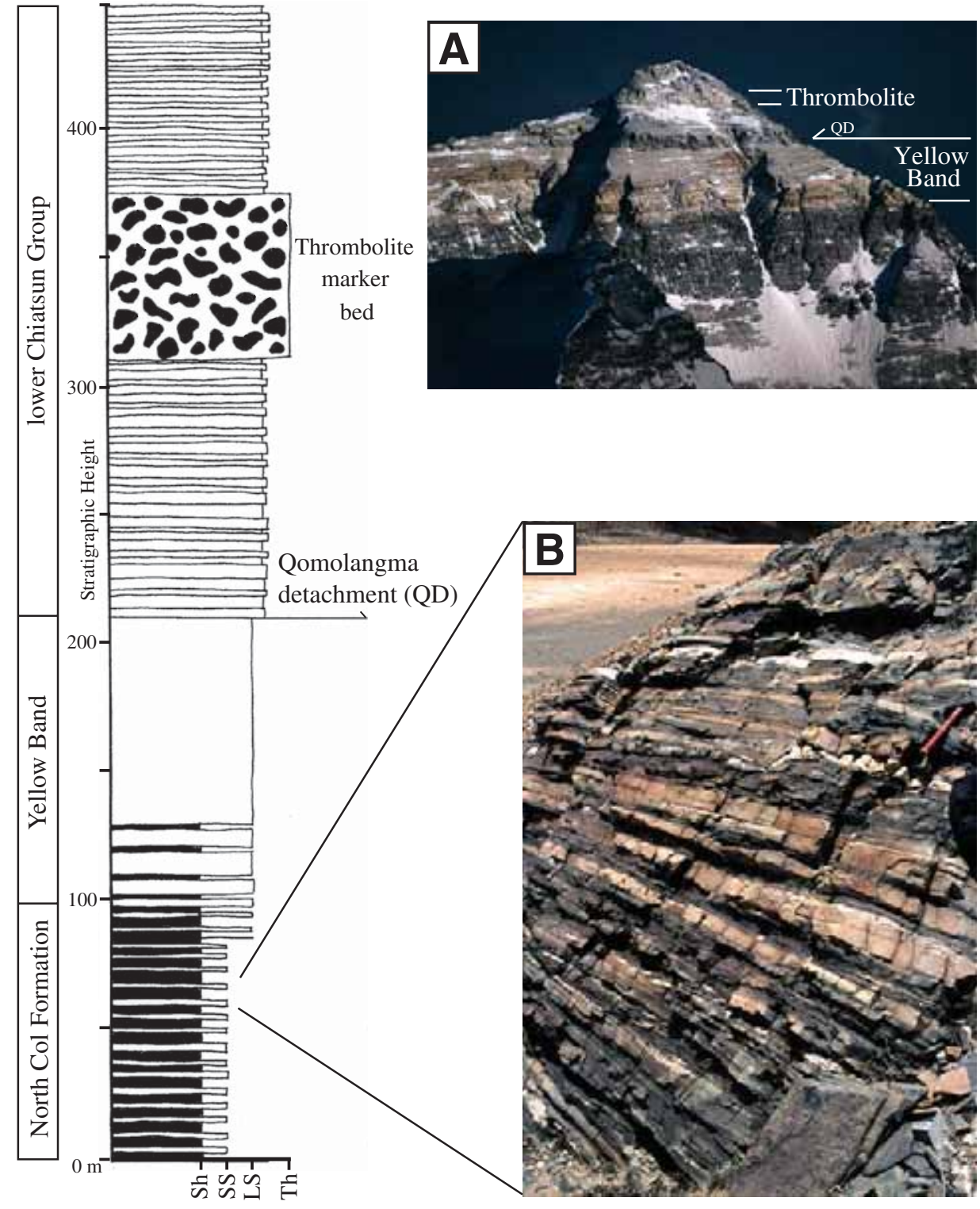

Figure 2. Stratigraphic section from Nyalam, Tibet. Lithologies along $x$-axis of measured section: Sh-shale, SS-sandstone, LS-limestone, Th-thrombolite. (A) Photograph of Mount Qomolangma (Everest) showing position of the Yellow Band, Qomolangma detachment (QD), and thrombolite unit. Yellow Band is $\sim 170 \mathrm{~m}$ thick. (B) Close-up of stratigraphic equivalent of the North Col Formation in Nyalam, Tibet, showing well-preserved bedding and stratification in Middle Cambrian strata. Hammer in upper right is $35 \mathrm{~cm}$ long.

et al., 2006a, 2006b). In localities across northern India, the upper part of the Parahio Formation contains a series of upward-thickening, orange-weathering carbonate beds (Fig. 3C), which in the Zanskar Valley of northern India grades into the carbonate of the Karsha Formation (Fig. 3B). This unit is locally absent along a sub-Ordovician unconformity in the Spiti Valley (Myrow et al., 2006a, 2006b) and Kumaon region (Fig. 4). Rocks of the Karsha Formation have a uniform texture and are similar in grain size, texture, and color to carbonate beds of both the underlying Parahio Formation and the Rouqiecun Group in Nyalam. The 109-m-thick, orange-weathering carbonate unit in Nyalam has similar thickness to the Karsha Formation (100-125 m; Garzanti et al., 1986; Figs. 3A and 3B), despite possible truncation by the South Tibetan detachment system. Thus, despite evidence of fairly intense shear in these rocks, and the presence of abundant quartz veins, primary bedding and a general stratigraphic succession 

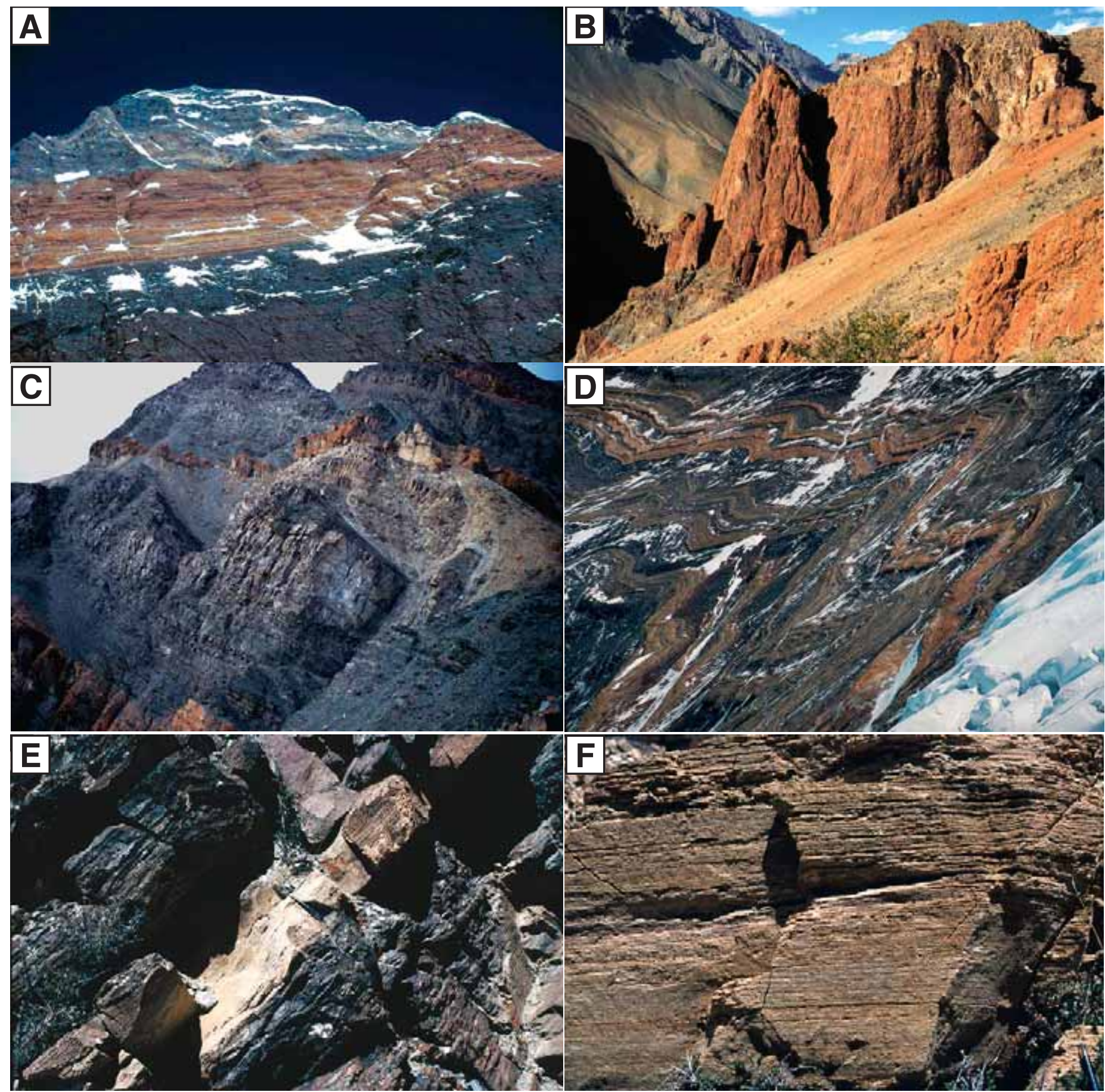

Figure 3. (A) Close-up of Yellow Band on the southwest face of Mt. Everest. (B) View of the orange dolostone of the Karsha Formation (> $100 \mathrm{~m}$ thick) in the Zanskar Valley region of northern India. Note underlying sandstone and shale (lower left), with interbeds of orange dolostone, of uppermost Parahio Formation. (C) Thick orange dolostone beds (lower left, middle, and upper right) of the upper Parahio Formation in the Parahio Valley of northern India. These beds are up to $13 \mathrm{~m}$ thick. (D) Lhotse calc-silicate bands at the headwall of the Western Cwm beneath Lhotse. (E) Orange-weathering dolostone bed from the Cambrian Rouqiecun Group in Nyalam. Hammer for scale. (F) Close-up of dolostone bed at Nyalam showing sheared internal structure. Pencil for scale in lower right. 
1. Zanskar Valley, India

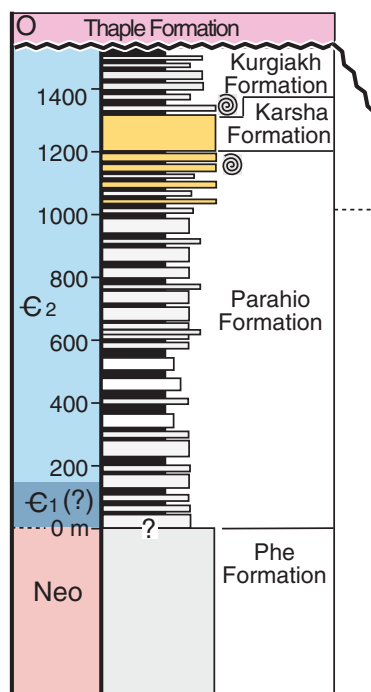

2. Spiti Valley, India

3. Kumaon Region, India
4. Nyalam, S. Tibet

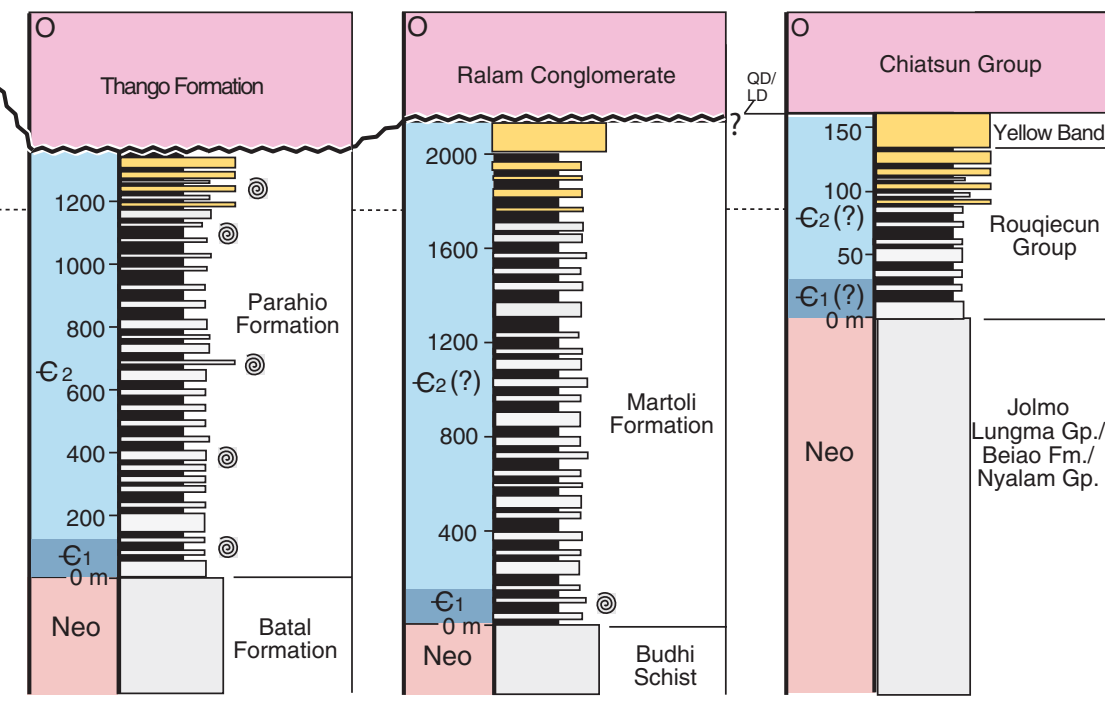

5. Qomolangma (Everest), Tibet

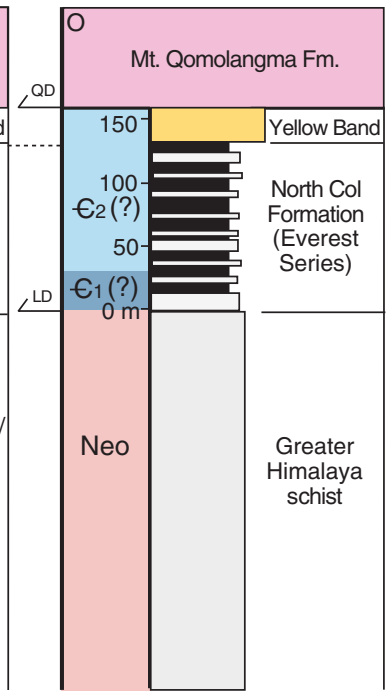

*Thicknesses of Ordovician and Neoproterozoic to Lower Cambrian deposits are not to scale

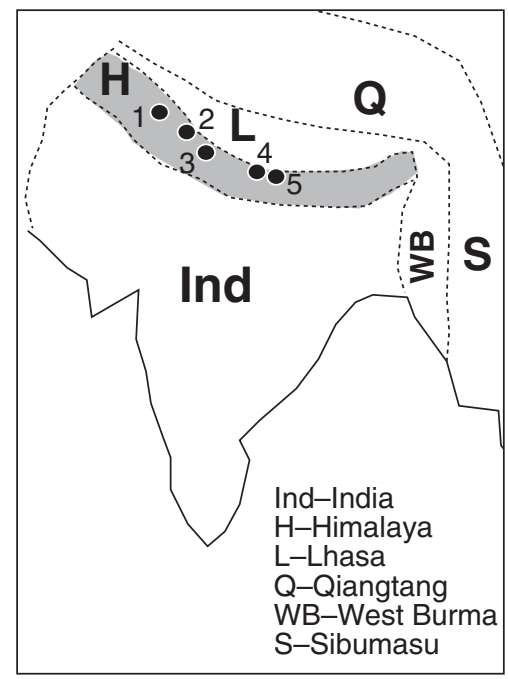

are preserved that match those of several sites across northern India. This succession is well correlated across that region, and the depositional ages, as determined by detailed trilobite biostratigraphy, are consistent and uniform in terms of faunal succession. The orange dolostone beds of the upper part of the Parahio Formation are also potentially correlated across the strike of the Himalaya, specifically, with the laterally extensive prominent calc-silicate bands of the Greater Himalaya, as seen at Lhotse and elsewhere (Figs. 3C and 3D).

The hanging wall of the South Tibetan detachment system in the Nyalam area consists of Ordovician limestone of the lower Chiatsun Group. The lower $105 \mathrm{~m}$ of the Ordovician rocks are composed of intensely fractured blue-
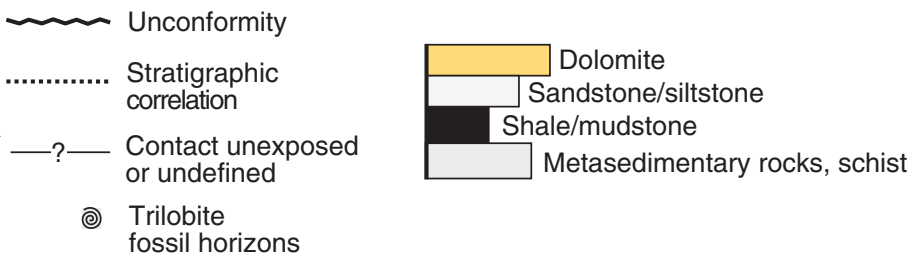

QD = Qomolangma Detachment

LD $=$ Lhotse Detachment

Figure 4. Cambrian stratigraphic sections with ages of strata and positions of trilobite fossil recovery. Data source: 1-Garzanti et al. (1986), Myrow et al. (2006a); 2-Brookfield (1993), Myrow et al. (2006b); 3-Kumar (1985), Brookfield (1993); 4-Zhang (1988); 5-Searle et al. (2003). Inset map shows position of sections and adjacent tectonic zones.

weathering limestone. A 65 -m-thick unit of pink- to white-weathering, massive limestone with a clotted texture overlies this limestone. The weathering pattern, uniform micritic composition, and clotted texture (Fig. 5) are typical of thrombolite deposits. Thrombolites are nonlaminated organosedimentary structures analogous to stromatolites but with a clotted internal structure, and these appear massive and homogeneous on most weathered surfaces.

\section{DETRITAL ZIRCON GEOCHRONOLOGY}

We collected a sandstone sample (NY-11) for $\mathrm{U}-\mathrm{Pb}$ detrital zircon geochronological analysis to determine whether the stratigraphic correlations outlined here would be supported by the resulting age spectra. The sample was taken from a sandstone bed in the upper Rouqiecun Group, $\sim 100 \mathrm{~m}$ below the contact with the orange-weathering dolostone unit. Detrital zircons were separated from the sample and dated with a sensitive highresolution ion microprobe (SHRIMP) at the Australian National University. Zircon grain ages for the sample $(n=60)$ are shown on a relative probability plot (Fig. 6) along with the detrital spectra from a sample (PV) of the Parahio Formation (Myrow et al., 2003) taken from the Spiti Valley of northern India. Samples were prepared and analyzed using standard procedures outlined by Williams and Claesson (1987) and Pell et al. (1997). 


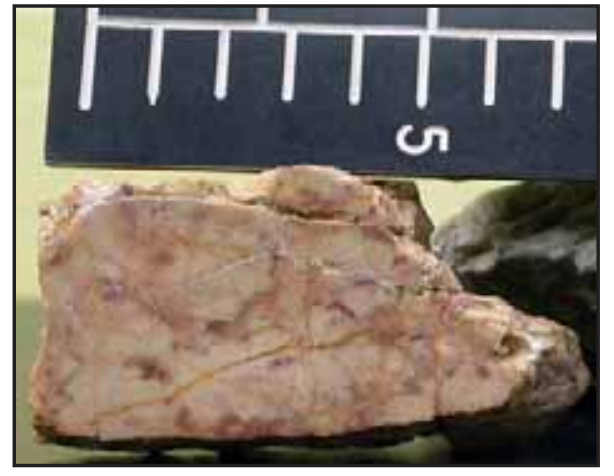

Figure 5. Thrombolite texture in hand sample taken from white-weathering unit in Nyalam (scale in cm).

Uncertainties given for individual analyses (ratios and ages) are at the $1 \sigma$ level (see GSA Data Repository $^{1}$ ). Correction for common $\mathrm{Pb}$ was either made using the measured ${ }^{204} \mathrm{~Pb} /{ }^{206} \mathrm{~Pb}$ ratio in the normal manner, or, for grains younger than ca. $800 \mathrm{Ma}$ (or those low in $\mathrm{U}$ and so radiogenic $\mathrm{Pb}$ ), the ${ }^{207} \mathrm{~Pb}$ correction method was used (see Williams, 1998). When the ${ }^{207} \mathrm{~Pb}$ correction is applied, it is not possible to determine radiogenic ${ }^{207} \mathrm{~Pb} /{ }^{206} \mathrm{~Pb}$ ratios or ages. In general, for grains younger than $800 \mathrm{Ma}$, the radiogenic ${ }^{206} \mathrm{~Pb} /{ }^{238} \mathrm{U}$ age was used for the probability density plots (and for areas that are low in $\mathrm{U}$ and therefore indicate radiogenic $\mathrm{Pb}$ ). The ${ }^{207} \mathrm{~Pb} /{ }^{206} \mathrm{~Pb}$ age was used for grains older than ca. $800 \mathrm{Ma}$, or for those areas enriched in U. Tera and Wasserburg (1972) concordia plots, probability density plots with stacked histograms, and weighted mean ${ }^{206} \mathrm{~Pb} /{ }^{238} \mathrm{U}$ age calculations were carried out using ISOPLOT/EX (Ludwig, 2003). The degree of discordance of the vast majority of the grains is quite low.

A comparison of the two samples clearly shows a similar distribution of detrital zircon ages and thus a similar provenance (Fig. 6). The ages of the two youngest grains (with $1 \sigma$ uncertainties) in NY-11 are $526 \pm 7$ Ma and $526 \pm 6 \mathrm{Ma}$, and these ages are consistent with a maximum depositional age of Early Cambrian. These data, in addition to our stratigraphic correlation, refute the claim, based on a SHRIMP U-Pb age of $686 \mathrm{Ma}$ and a whole-rock $\mathrm{Rb}-\mathrm{Sr}$ age of $796 \mathrm{Ma}$, that the entirety of the Rouqiecun Group is Neoproterozoic (Zou et al., 2006). The youngest zircon ages are consistent with our inferred depositional age of middle

${ }^{1}$ GSA Data Repository Item 2008214, detrital zircon $\mathrm{U}-\mathrm{Pb}$ age data, is available, is available at www.geosociety.org/pubs/ft2008.htm. Requests may also be sent to editing@geosociety.org.

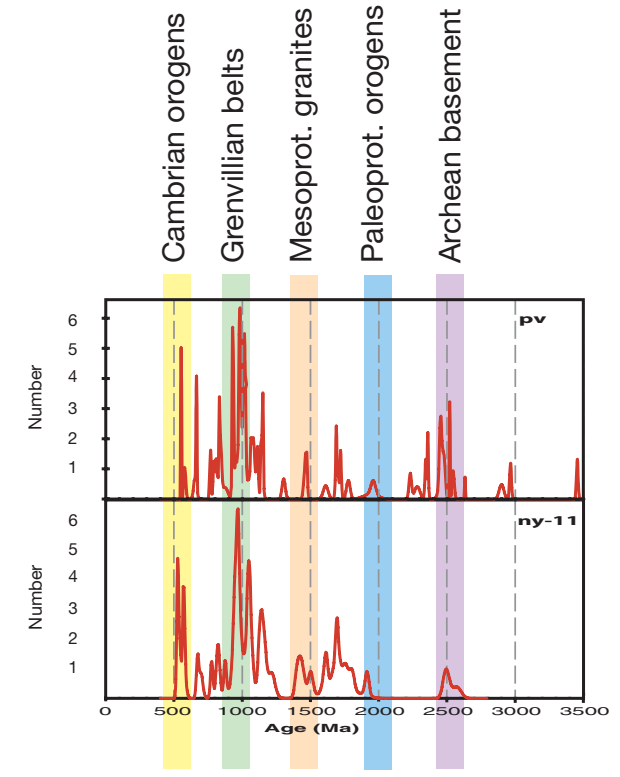

Figure 6. Detrital zircon age spectra from Nyalam, Tibet, sample (NY-11) and Parahio (northern India) sample (PV). Important age peaks are shown in color bands. Note similarity of spectra between samples.

Middle Cambrian for the upper Rouqiecun Group, which sits below the dolostone unit in Nyalam. This age is based on biostratigraphic data from the Parahio Formation, which has a similar stratigraphic position (below the carbonate of the Karsha Formation). Trilobite fossils in the Parahio Formation in the Parahio and Zanskar valleys indicate that the unit ranges from uppermost Lower Cambrian (near top of informal stage 4 of the Cambrian System) to middle Middle Cambrian (middle part of informal stage 5). Based on our stratigraphic correlations and known thicknesses of Cambrian strata along the Indian margin (e.g., $\sim 1300 \mathrm{~m}$ of mostly Middle Cambrian strata in the Parahio Valley), a great majority of the thickness of the Rouqiecun Group may be Cambrian. In fact, the age of the orange carbonate unit is also Middle Cambrian, given that latest Middle Cambrian trilobites have been recovered from the lower member of the Kurgiakh Formation, the unit above the carbonate Karsha Formation in Zanskar, from several localities (Whittington, 1986; Jell and Hughes, 1997; Hughes, 2002; Myrow et al., 2006b). In summary, both the shape of the detrital zircon age spectra and the ages of the youngest detrital grains support the stratigraphic correlations between northern India and the Nyalam region of southern Tibet, and they suggest a continuity of Cambrian depositional systems along the northern margin of East Gondwanaland.

\section{STRATIGRAPHY: EVEREST}

Strata correlative with those of the Nyalam area have been mapped in the Everest region (Gysin and Lombard, 1960; Burchfiel et al., 1992; Searle, 2003), and we examined them at the roadside locality $18 \mathrm{~km}$ north of Rongbuk Monastery. These include the metamorphosed sandstone and shale deposits of the North Col Formation, which are identical in character to the Rouqiecun Group, and a yellow-weathering carbonate unit of similar character to that in Nyalam. These units can be traced directly onto Everest itself. We correlate these units with the Parahio and Karsha Formations in northern India, respectively (Fig. 4).

The thicknesses of various units on Everest have been estimated based on precise elevation data and photographic interpretation. The base of the famous Yellow Band (Figs. 2 and 3A), a regional marker unit of calcite-rich coarsegrained marble (Jessup et al., 2006), is placed at $8348 \mathrm{~m}$, and its top is placed at $8520 \mathrm{~m}$. The calculated thickness of $172 \mathrm{~m}$ is $63 \mathrm{~m}$ thicker than the yellow carbonate unit near Nyalam, but its top is the Qomolangma detachment and so the upper part may have been cut out by normal faulting at Nyalam.

The entire upper part of Everest, above the Yellow Band, has been mapped as the Mount Qomolangma Formation, a succession of gray, dominantly fine-grained Ordovician limestone (Sakai et al., 2005). Most of these strata consist of highly recrystallized sandy limestone (Jessup et al., 2006; Fig. 6A). These strata dip at $\sim 15^{\circ}$ to the NNE on the summit of Everest but flatten out to $<5^{\circ}$ along the Rongbuk glacier (Searle et al., 2003). They rest directly above the Qomolangma detachment, the upper strand of the South Tibetan detachment system. The age-equivalent strata in the Nyalam region, the Lower Chiatsun Group, are similar in lithology and show a very similar stratigraphic succession (Burchfiel et al., 1992). The limestone of the lower Chiatsun Group is considered to be Lower to Middle Ordovician in age based on nautaloid, brachiopod, and conodont assemblages (Yin and Kuo, 1978; Yin, 1987; Burchfiel et al., 1992). In the Everest region, the Qomolangma Formation is mainly made up of gray thick-bedded micritic limestone, and its total thickness is $225 \mathrm{~m}$ in the summit area. On the basis of a fossil assemblage of brachiopods, collected from the northern continuation of the summit limestone, the age of the Qomolangma Formation has been assigned to the Early-Middle Ordovician (Yin and Kuo, 1978; Yin, 1987).

A prominent white-weathering bed exists on Everest within the Mount Qomolangma Formation, the base of which is at the foot of the 
"Third Step," which marks the bottom of the summit pyramid (Fig. 2). On Everest, the top of the Yellow Band marks the base of the "First Step" along the North-East Ridge. Based on elevation data and photographic interpretation, the white-weathering bed on Everest is $\sim 60 \mathrm{~m}$ thick, and its base lies $\sim 110 \mathrm{~m}$ above the top of the Yellow Band. Compared to the thick prominent thrombolite marker bed at Nyalam, this whiteweathering bed on Everest that makes up the base of the summit pyramid is nearly identical in thickness (60 versus $65 \mathrm{~m}$ ) and stratigraphic height above the prominent yellow dolostone marker beds ( 110 versus $105 \mathrm{~m})$. The correlation is striking and indicates that the base of the summit pyramid is a continuation of the thrombolite bed from Nyalam.

Samples taken from $6 \mathrm{~m}$ below the summit of Everest consist of a variety of generally finegrained marine carbonate deposits with variable amounts of land-derived silt and clay (Sakai et al., 2005). Grains in the limestone include fragments of crinoids and trilobites, as well as peloids (sand-sized fossilized fecal pellets). These deposits are presumably much less deformed than the rest of the Mount Qomolangma Formation above the white thrombolite bed, which are too intensely sheared to contain well-preserved fossil fragments (Jessup et al., 2006).

\section{DISCUSSION}

Previous workers have suggested that increased metamorphic grade eastward along the Himalaya (Brookfield, 1993), and marked differences in regional lithostratigraphy (Garzanti, 1999), frustrate attempts to correlate Cambrian rocks along the length of the Tethyan Himalaya. Although early Himalayan (late Eocene-early Oligocene) ultrahighpressure eclogites have only been found in the Western Himalaya (Kaghan, Pakistan, and Tso Morari, India), Oligocene-early Miocene kyanite- and sillimanite-grade metamorphism reached similar pressure and temperature conditions along the entire length of the Himalaya, at least from Zanskar to Everest (e.g., Searle et al., 2003, 2006, 2007). Our integration of extensive sedimentological and lithostratigraphic analysis with new biostratigraphic and detrital zircon geochronologic data indicates that a coherent Cambrian stratigraphy can be traced along a major length of the Himalaya (Fig. 4). In addition, we correlate extensive carbonate beds of the upper Parahio Formation with calc-silicate beds of Unit II of the Greater Himalaya (Figs. 3C, 3D, and 7), supporting a continuity of stratigraphy across the strike of the Himalaya.
Here, our approach allows for the determination of depositional ages of strata that lack preserved fossils, in this case, the Rouqiecun Group-North Col Formation and the Yellow Band of southern Tibet. Similarities in the detrital zircon age spectra from Nyalam and the Spiti Valley of northern India indicate that depositional systems and sediment dispersal were relatively uniform along the length of the Tethyan Himalayan margin during the Cambrian. The ages of the youngest zircon grains in the Nyalam sample are consistent with, although not diagnostic of, the Middle Cambrian age determined from our correlations to northern India.

Correlation between the Nyalam and Everest sections, the thickness of the white marker bed at both localities, and the distance from the Qomolangma detachment to the bed all indicate that the base of the "Third Step," which marks the foot of the summit pyramid, consists of an 60-m-thick thrombolite unit (Fig. 5). Thrombolites are common microbial deposits in Ordovician rocks (Armella, 1994; Turner et al., 2000), from which layers up to hundreds of meters thick have been reported (de Freitas and Mayr, 1995). This microbial buildup, the top of which is only $70 \mathrm{~m}$ below the Everest summit, was a regionally extensive deposit in

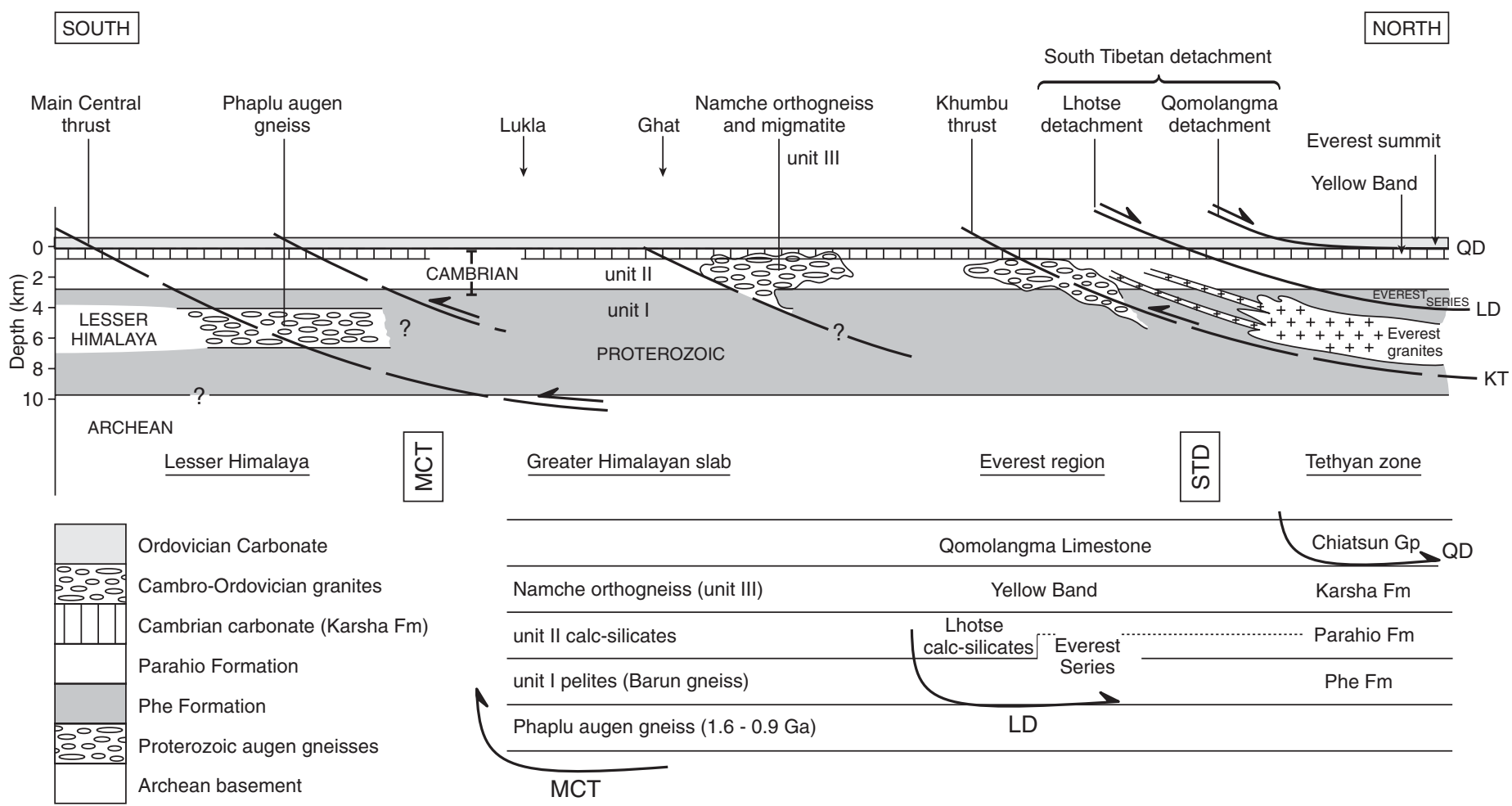

Figure 7. Restored section across the Himalaya in the Everest region showing a simplified stratigraphy and the position of major shear zones and faults (modified from Searle et al., 2006). The correlative units of Tethyan Cambrian units from northern India are provided on the right (Phe, Parahio, and Karsha Formations). 
this region of the Tethyan margin in the Ordovician. The correlation of the Ordovician rocks on Everest with those in the Spiti Valley is less clear. In Spiti, the lowermost Ordovician rocks consist of a thick succession of red siliciclastic synorogenic strata that is overlain by limestone no older than Middle Ordovician in age. The base of the Ordovician limestone of the Everest region may be slightly older, and there is no evidence of the underlying siliciclastic unit that is found across northern India, although this may have been removed by faulting along the Qomolangma detachment.

The correlations outlined here also have implications for the tectonic and structural history of the rocks of the Everest region and the Himalaya in general. The correlation is particularly important for understanding the spatial geometry and nature of the South Tibetan detachment system (Fig. 8). Along the Zanskar Valley of northern India, the South Tibetan detachment system is placed at the base of the Phe Formation, the basal unit of the Haimanta Group in that area (Vannay and Grasemann, 1998). The unfossiliferous Phe Formation rests directly below the trilobite-bearing uppermost Lower to Middle Cambrian Parahio Formation. The contact with the high-grade metamorphic rocks of the Greater Himalaya sequence is clearly defined and observed along the trace of the Zanskar shear zone in the west (Searle et al., 1992, 1999; Walker et al., 1999) and the Sangla detachment fault further east (Steck et al., 1993). Restoration of the Greater Himalaya sequence in Zanskar and Ladakh reveals the continuity of the Proterozoic protolith rocks of the Greater Himalaya sequence with similar-age rocks both from the Lesser Himalaya below the Main Central thrust and the base of the Tethyan Himalaya, north of the Zanskar shear zone or South Tibetan detachment (Fig. 7; Searle et al., 2007).

In the Everest region of Nepal and South Tibet, the South Tibetan detachment system shows two strands, the upper Qomolangma detachment and the lower ductile Lhotse detachment (Searle et al., 2003, 2006; Jessup et al., 2006), and the North Col Formation (= Everest Series) and Yellow Band are sandwiched between the two. The Qomolangma detachment is a contact between the greenschist- to lower-amphibolitefacies Middle Cambrian rocks below and the less metamorphosed, brittlely deformed Ordovician strata above (e.g., Burchfiel et al., 1992). On the basis of our study, the Zanskar and Sangla fault zones are directly correlative with the Lhotse detachment of the South Tibetan detachment system in the Everest region (Fig. 8), as outlined by Searle et al. (2003, 2006). The preservation of original bedding and relict stratigraphy in parts of the North Col Formation rocks between the two strands of the South Tibetan detachment system (Fig. 8) indicates that despite strong shearing and peak metamorphic temperatures of $450{ }^{\circ} \mathrm{C}$ (Jessup et al., 2006), these strata were not subjected to high-grade metamorphism and the development of ductile-flow fabrics typical of the Greater Himalaya sequence. They also lack leucogranite sills and dikes. Rocks beneath the Lhotse detachment consist of sillimanite + garnet \pm cordierite gneisses with abundant partial melting and leucogranite sills, characteristics that have been interpreted as the result of ductile extrusion during early Miocene channel flow (Searle, 1999, 2003; Searle et al., 2003, 2006; Jessup et al., 2006; Cottle et al., 2007).

The two South Tibetan detachment shear zones on Everest merge toward the north (Rongbuk) and west (Nyalam), so that one large-scale ductile shear zone of Cambrian strata is capped by a low-angle brittle normal fault (Searle, 2003; Searle et al., 2003, 2006). North of Rongbuk, at deeper structural levels in the Dzakaa Chu section, the South Tibetan detachment is a 1000-m-thick ductile shear zone dipping at $35^{\circ}$ to the north that places Ordovician and younger sedimentary rocks above sheared Cambrian calc-silicates and mylonites (Cottle et al., 2007). In the Nyalam area, the Cambrian strata rest below the combined Lhotse and Qomolangma

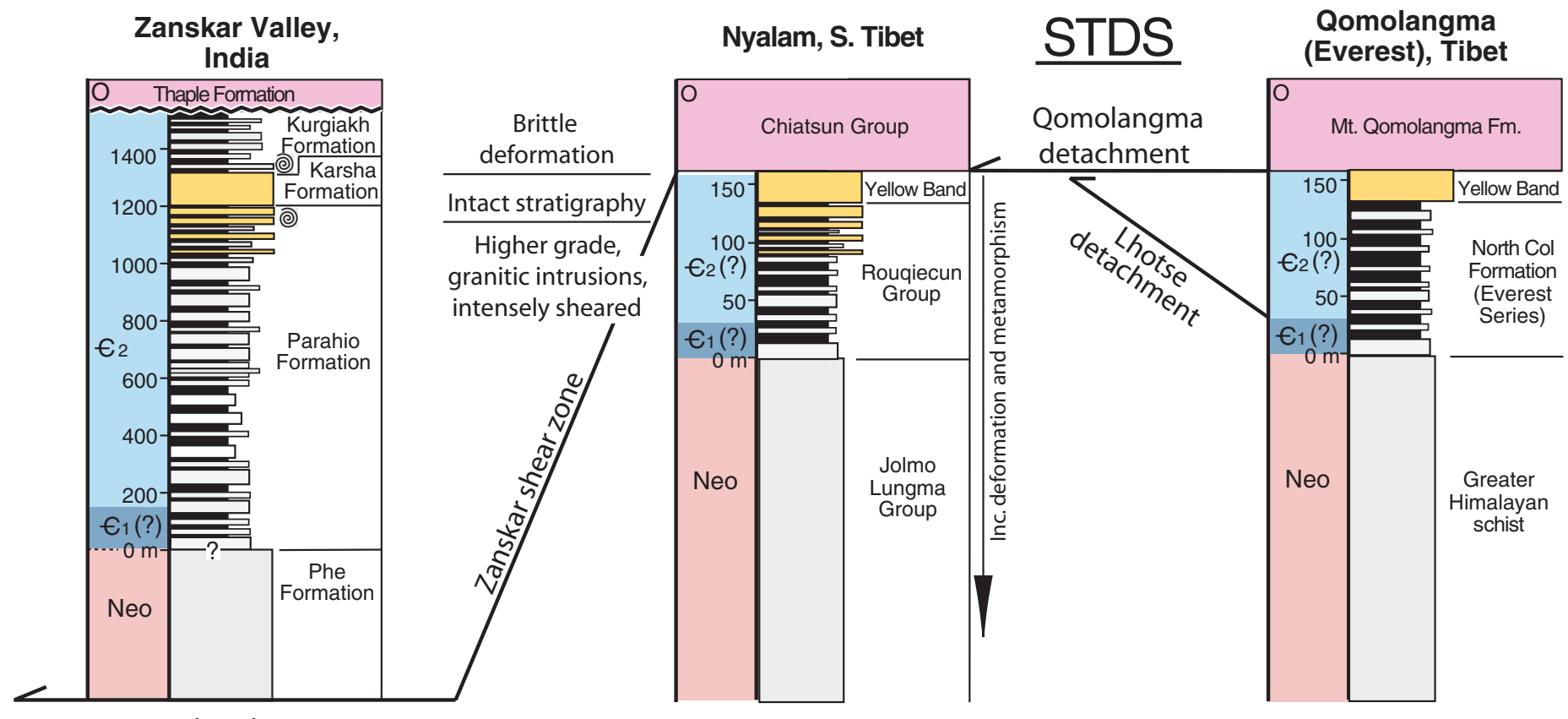

Zanskar shear zone

Figure 8. Close-up of sections from Nyalam and Qomolangma showing the structural relationships between the two sections. Note the stratigraphic position of the Parahio Formation and age-equivalent strata, the North Col Formation and Rouqiecun Group. The North Col Formation sits above the Lhotse detachment on Everest, the Rouqiecun Group is below the merged detachments at Nyalam, and the Parahio Formation sits above the Zanskar shear zone in the Zanskar Valley. STDS-South Tibetan detachment system. 
detachment faults, instead of between the two, as on the Everest massif. Despite this, and the fact that the Nyalam strata have abundant leucogranite sills and dikes, preserved bedding and coherent stratigraphy are found in the $\sim 200 \mathrm{~m}$ directly below the South Tibetan detachment system in Nyalam (Fig. 8). Below this zone of relatively intact strata, the metamorphic grade and degree of deformation increase rapidly (Burg et al., 1984; Burchfiel et al., 1992). In other words, ductile strain and metamorphism associated with movement along the South Tibetan detachment system diminished rapidly near the top of the ductile shear zone. Restoration of the South Tibetan detachment system normal faults shows that the merged Qomolangma and Lhotse detachments cut down stratigraphic section to the north (Fig. 8; Searle et al., 2003), as expected for a normal fault, along the length of the Himalaya, to form the Zanskar shear zone in northwest India, which sits in this case below relatively unmetamorphosed Middle Cambrian and older strata. As such, the Middle Cambrian strata of the Parahio and Karsha Formations in northern India, and their equivalents in Tibet (Rouqiecun Group, North Col Formation, and Yellow Band), sit below the South Tibetan detachment system (Nyalam), between the two strands of the South Tibetan detachment system (Everest), and above the South Tibetan detachment system (north India) in different parts of the Himalaya. Recognition of these strata as a coherent lithostratigraphic unit of consistent age helps define the exact geometric relationships of this major fault zone and associated metamorphic and deformational history along the length of the orogen.

\section{ACKNOWLEDGMENTS}

This work was supported by the following grants: National Science Foundation (NSF) EAR-9980376 and EAR-0543340 to Myrow, EAR-9980426 and EAR-053868 to Hughes, an Natural Environment Research Council (NERC; UK) grant to Searle (NER/K/S/2000/00951), and MTS and CAS (China) grants to Peng (2006CB806408, 2006FY120300, KZCX2-YW-122). The authors thank Associate Editor Peter Cawood, reviewer Sam Bowring, and an anonymous reviewer for their valuable input.

\section{REFERENCES CITED}

Armella, C., 1994, Thrombolitic-stromatolitic cycles of the Cambro-Ordovician boundary sequence, Precordillera Oriental Basin, western Argentina, in Bertrand-Sarfati, J., and Monty, C.L.V., eds., Phanerozoic Stromatolites II: Dordrecht, Netherlands, Kluwer Academic, p. 421-441.

Brookfield, M.E., 1993, The Himalayan passive margin from Precambrian to Cretaceous times: Sedimentary Geology, v. 84, p. 1-35, doi: 10.1016/0037-0738(93)90042-4

Burchfiel, B.C., Chen, Z., Hodges, K.V., Liu, Y., Royden, L.H., Deng, C., and Xu, J., 1992, The south Tibetan detachment system, Himalayan orogen: Extension contemporaneous with and parallel to shortening in a collisional mountain belt: Geological Society of America Special Paper 29, p. 1-41
Burg, J.P., 1983, Carte Géologique du Sud du Tibet: Beijing, Ministry of Geology, and Paris, Centre National De La Recherche Scientifique, scale 1:500,000

Burg, J.P., Brunel, M., Gapais, D., Chen, G.M., and Liu, G.H., 1984, Deformation of leucogranites of the crystalline Main Central thrust sheet in southern Tibe (China): Journal of Structural Geology, v. 6, p. 535 542, doi: 10.1016/0191-8141(84)90063-4.

Carosi, R., Lombardo, B., Molli, G., Musumeci, G., and Pertusati, P., 1998, The South Tibetan detachment system in the Rongbuk valley, Everest region: Deformation features and geological implications: Journal of Asian Earth Sciences, v. 16, p. 299-311, doi: 10.1016/ S0743-9547(98)00014-2

Cottle, J.M., Jessup, M.J., Newell, D.L., Searle, M.P., Law, R.D., and Horstwood, M.S.A., 2007, Structural insights into the early stages of exhumation along an orogen-scale detachment: The South Tibetan detachment system, Dzakaa Chu section, Eastern Himalaya: Journal of Structural Geology, v. 29, p. 1781-1797, doi: 10.1016/j.jsg.2007.08.007

de Freitas, T., and Mayr, U., 1995, Kilometre-scale microbial buildups in a rimmed carbonate platform succession, Arctic Canada: New insight on Lower Ordovician reef facies: Bulletin of Canadian Petroleum Geology, v. 43, p. $407-432$.

Gansser, A., 1964, Geology of the Himalayas: London, Interscience Publications, $289 \mathrm{p}$

Garzanti, E., 1999, Stratigraphy and sedimentary history of the Nepal Tethys Himalaya passive margin: Journal of Asian Earth Sciences, v. 17, p. 805-827, doi: 10.1016/S1367-9120(99)00017-6.

Garzanti, E., Casnedi, R., and Jadoul, F., 1986, Sedimentary evidence of a Cambro-Ordovician orogenic even in the northwestern Himalaya: Sedimentary Geology, v. 48, p. 237-265, doi: 10.1016/0037-0738(86)90032-1.

Gysin, M., and Lombard, A., 1960, Observations complémentaires de pétrographie et de géologie dans le Massif du Mont Everest-Lhotse: Eclogae Geologicae Helvetiae, v. 53, p. 189-204

Hughes, N.C., 2002, Late Middle Cambrian trace fossils from the Lejopyge armata horizon, Zanskar Valley, India, and the use of Precambrian/Cambrian ichnostratigraphy in the Indian subcontinent: Special Paper in Palaeontology, v. 67, p. 135-151.

Jell, P.A., and Hughes, N.C., 1997, Himalayan Cambrian trilobites: Special Papers in Palaeontology, v. 58, p. 1-113.

Jessup, M.J., Law, R.D., Searle, M.P., and Hubbard, M.S. 2006, Structural evolution and vorticity of flow during extrusion and exhumation of the Greater Himalayan Slab, Mount Everest Massif, Tibet/Nepal: Implications for orogen-scale flow partitioning, in Law, R.D. Searle, M.P., and Godin, L., eds., Channel Flow, Ductile Extrusion and Exhumation in Continental Collision Zones: Geological Society of London Special Publication 268, p. 379-413.

Kumar, R., 1985, Fundamentals of historical geology and stratigraphy of India: New Delhi, Wiley Eastern Limited, p. 81-83.

Law, R.D., Searle, M.P., and Simpson, R.L., 2004, Strain, deformation temperatures and vorticity of flow at the top of the Greater Himalayan Slab, Everest Massif, Tibet: Journal of the Geological Society of London, v. 161, p. 305-320, doi: 10.1144/0016-764903-047.

Liu, G., and Einsele, G., 1994, Sedimentary history of the Tethyan basin in the Tibetan Himalayas: Geologische Rundschau, v. 83, p. 32-61, doi: 10.1007/BF00211893.

Lombardo, B., Pertusati, P., and Borgi, S., 1993, Geology and tectonomagmatic evolution of the eastern Himalaya along the Chomolungma-Makalu transect, in Treloar, P.J., and Searle, M.P., eds., Himalayan Tectonics: Geological Society of London Special Publication 74, p. 341-355.

Ludwig, K.R., 2003, Isoplot/Ex Version 3.0: A Geochronological Toolkit for Microsoft Excel: Berkeley Geochronology Center Special Publication 4, 71 p.

Mu, A.T., Wen, S.H., Wang, Y.K., Chang, P.K., and Yin, C.H., 1973, Stratigraphy on Mount Jolmo Lungma region of Southern Tibet: Scientia Sinica, v. 16, p. 96-111.

Myrow, P.M., Hughes, N.C., Paulsen, T., Williams, I., Parcha, S.K., Thompson, K.R., Bowring, S.A., Peng, S.-C., and Ahluwalia, A.D., 2003, Integrated tectono- stratigraphic analysis of the Himalaya and implications for its tectonic reconstruction: Earth and Planetary Science Letters, v. 212, p. 433-441, doi: 10.1016/ S0012-821X(03)00280-2.

Myrow, P.W., Thompson, K.R., Hughes, N.C., Paulsen, T.S., Sell, B.K., and Parcha, S.K., 2006a, Cambrian stratigraphy and depositional history of the northern Indian Himalaya, Spiti Valley, north-central India: Geological Society of America Bulletin, v. 118, p. 491-510, doi: 10.1130/B25828.1.

Myrow, P.W., Snell, K.E., Hughes, N.C., Paulsen, T.S., Heim, N.A., and Parcha, S.K., 2006b, Cambrian depositional history of the Zanskar Valley region of the Indian Himalaya: Tectonic implications: Journal of Sedimentary Research, v. 76, p. 364-381, doi: 10.2110/jsr.2006.020.

Odell, N.E., 1925, Observations on the rocks and glaciers of Mount Everest: The Geographical Journal, v. 66, p. 289-313, doi: 10.2307/1782942.

Pell, S.D., Williams, I.S., and Chivas, A.R., 1997, The use of protolith zircon-age fingerprints in determining the protosource areas for some Australian dune sands: Sedimentary Geology, v. 109, p. 233-260, doi: 10.1016/S0037-0738(96)00061-9.

Sakai, H., Sawada, M., Takigami, Y., Orihashi, Y., Danhara, T., Iwano, H., Kuwahara, Y., Dong, Q., Cai, H., and Li, J., 2005, Geology of the summit limestone of Mount Qomolangma (Everest) and cooling history of the Yellow Band under the Qomolangma detachment: The Island Arc, v. 14, p. 297-310, doi: 10.1111/ j.1440-1738.2005.00499.x.

Searle, M.P., 1999, Extensional and compressional faults in the Everest-Lhotse Massif, Khumbu Himalaya, Nepal: Journal of the Geological Society of London, v. 156, p. 227-240, doi: $10.1144 /$ gsjgs.156.2.0227.

Searle, M.P., 2003, Geological Map of the Mount Everest Massif, Nepal-South Tibet Himalaya: Oxford, Oxford University Press, scale 1:100,000.

Searle, M.P., Waters, D.J., Rex, D.C., and Wilson, R.N., 1992, Pressure, temperature and time constraints on Himalayan metamorphism from eastern Kashmir and western Zanskar: Journal of the Geological Society of London, v. 149, p. 753-773, doi: 10.1144/gsigs.149.5.0753.

Searle, M.P., Waters, D.J., Dransfield, M.W., Stephenson, B.J., Walker, C.B., Walker, J.D., and Rex, D.C., 1999. Thermal and mechanical models for the structural and metamorphic evolution of the Zanskar High Himalaya, in Mac Niocaill, C., and Ryan, P.D., eds., Continental Tectonics: Geological Society of London Special Publication 164, p. 139-156, doi: 10.1144/ GSL.SP.1999.164.01.08

Searle, M.P., Simpson, R.L., Law, R.D., Parrish, R.R., and Waters, D.J., 2003, The structural geometry, metamorphic and magmatic evolution of the Everest Massif, High Himalaya of Nepal-South Tibet: Journal of the Geological Society of London, v. 160, p. 345-366, doi: 10.1144/0016-764902-126.

Searle, M.P., Law, R.D., and Jessup, M.J., 2006, Crustal structure, restoration and evolution of the Greater Himalaya in Nepal-South Tibet: Implications for channel flow and ductile extrusion of the middle crust, in Law, R.D., Searle, M.P., and Godin, L., eds., Channel Flow, Ductile Extrusion and Exhumation in Continental Collision Zones: Geological Society of London Special Publication 268, p. 379-413.

Searle, M.P., Stephenson, B.J., Walker, J.D., and Walker, C.B., 2007, Restoration of the western Himalaya: Implications for metamorphic protoliths, thrust and normal faulting, and channel flow models: Episodes, v. 30 , no. 4 , p. $242-257$.

Steck, A., Spring, L., Vannay, J.C., Masson, H., Stutz, E., Bucher, H., Marchant, R., and Tieche, J.C., 1993, Geological transect across the northwestern Himalaya in eastern Ladakh and Lahul (a model for the continental collision of India and Asia): Eclogae Geologicae Helvetiae, v. 86 , p. 219-263.

Tera, F., and Wasserburg, G., 1972, U-Th-Pb systematics in three Apollo 14 basalts and the problem of initial $\mathrm{Pb}$ in lunar rocks: Earth and Planetary Science Letters, v. 14, p. 281-304, doi: 10.1016/0012-821X(72)90128-8.

Turner, E.C., James, N.P., and Narbonne, G.M., 2000, Taphonomic control on the microstructure in early 


\section{Myrow et al.}

Neoproterozoic reefal stromatolites and thrombolites: Palaios, v. 15 , p. $87-111$.

Vannay, J.C., and Grasemann, B., 1998, Himalaya inverted metamorphism in the High Himalaya of Kinnaur (NW India): Petrography versus thermobarometry: Schweizerische Mineralogische und Petrographische Mitteilungen, v. 78, p. 107-132.

Wager, L.R., 1934, A review of the geology and some new observations, in Ruttledge, H., ed., Everest 1933: London, Hodder and Stoughton, p. 312-336.

Wager, L.R., 1965, Injected granite sheets of the Rongbuk valley and the north face of Mount Everest, in Jhingran, A.J., ed., D.N. Wadia commemorative volume: India Mining, Geology and Metallurgy Institute, p. $358-379$.

Walker, J.D., Martin, M.W., Bowring, S.A., Searle, M.P., Waters, D.J., and Hodges, K.V., 1999, Metamorphism, melting and extrusion: Age constraints from the High Himalayan slab of southeast Zanskar and northwest Lahaul: The Journal of Geology, v. 107, p. 473-495, doi: $10.1086 / 314360$
Wang, Z., and Zhen, X., 1975, Imbricate structure in the northern slope of Jolmo Lungma and discussion on the uplift of the Himalaya, in Scientific Exploration of Jolmo Lungma: Beijing, Science Publishing House, p. 199-221.

Whittington, H.B., 1986, Late Middle Cambrian trilobites from Zanskar, Ladakh, northern India: Rivista Italiana di Paleontologia e Stratigrafia, v. 92, p. 171-188.

Williams, I.S., 1998, U-Th-Pb geochronology by ion microprobe, in McKibben, M.A., et al., eds., Applications of Microanalytical Techniques to Understanding Mineralizing Processes: Reviews in Economic Geology, v. 7, p. 1-35.

Williams, I.S , and Claesson, S., 1987, Isotopic evidence for the Precambrian provenance and Caledonian metamorphism of high-grade paragneisses from the Seve Nappes, Scandinavian Caledonides: 2. Ion microprobe zircon U-Th-Pb: Contributions to Mineralogy and Petrology, v. 97 , p. $205-217$, doi: $10.1007 / \mathrm{BF} 00371240$.

Yin, C.-H., and Kuo, S.-T., 1978, Stratigraphy of the Mount Jolmo Lungma and its north slope: Scientia Sinica, v. 21 , p. $629-644$
Yin, J.-X., 1987, Cambro-Ordovician System, in Su, Z.-W., ed., Stratigraphy of the Mount Qomolangma Region: Beijing, Sciences Press, p. 5-26.

Zhang reference: Zhang, W.T., 1988, The Cambrian System in Eastern Asia, correlation chart and explanatory notes, in Shergold, J.H., and Palmer, A.R., eds., International Union of Geological Sciences Publication 24, p. 1-81.

Zou, G.-F., Zhu, T.-X., Jia, B.-J., and Zhou, M.-K., 2006, Precambrian crystalline basement in the Nyalam region, southern Xizang (Tibet): Sedimentary Geology and Tethyan Geology, v. 26, p. 13-21.

Manuscript Received 4 December 2007

Revised Manuscript Received 6 July 2008

MANUSCRIPT ACCEPTED 9 July 2008

Printed in the USA 